\title{
The prevalence of metabolic syndrome in Latin America: a systematic review
}

\author{
F Márquez-Sandoval 1,2,3, G Macedo-Ojeda 1,2,3, D Viramontes-Hörner ${ }^{1,3}$, \\ JD Fernández Ballart ${ }^{4,5}$, J Salas Salvadó ${ }^{, 6}$ and B Vizmanos ${ }^{1,2,3, *}$ \\ ${ }^{1}$ Cuerpo Académico 454 'Alimentación y Nutrición en el proceso Salud-Enfermedad', Laboratorio de \\ Evaluación del Estado Nutricio, Departamento de Clínicas de la Reproducción Humana, Crecimiento y \\ Desarrollo Infantil, División de Disciplinas Clínicas, Centro Universitario de Ciencias de la Salud, Universidad \\ de Guadalajara. Calle Hospital 320, first floor (Antigua Escuela de Medicina, Universidad de Guadalajara), \\ 44280 Guadalajara, Jalisco, México: ${ }^{2}$ Doctorado en Ciencias de la Salud Pública, Centro Universitario de \\ Ciencias de la Salud, Universidad de Guadalajara, Jalisco, México: ${ }^{3}$ Licenciatura en Nutrición, Centro \\ Universitario de Ciencias de la Salud, Universidad de Guadalajara, Jalisco, México: ${ }^{4}$ Unitat de Medicina \\ Preventiva y Salud Pública, Facultat de Medicina i Ciències de la Salut, IISPV, Universitat Rovira i Virgili, Reus, \\ España: ${ }^{5}$ CIBER Fisiopatología de la Obesidad y Nutrición (CIBERobn), Instituto de Salud Carlos III (ISCIII), \\ España: 'Unitat de Nutrició Humana, Facultat de Medicina i Ciències de la Salut, Hospital Universitari de \\ Sant Joan de Reus, IISPV, Universitat Rovira i Virgili, Reus, España
}

Submitted 9 July 2010: Accepted 20 0ctober 2010: First published online 13 April 2011

\begin{abstract}
Objective: To assess the available data on the prevalence of metabolic syndrome (MS) in Latin-American countries.

Design: Systematic review. Searches were carried out in PubMed, ISIWeb, SCielo and Redalyc, using 'metabolic syndrome x' and 'prevalence' as keywords for titles and/or abstracts. Articles selected were cross-sectional studies in Latin-American countries, whose main objective was to study MS and whose study population is described below. MS must be determined using Adult Treatment Panel III criteria. Twelve studies with these criteria were selected, one of which was multi-centric. Setting: Latin America.

Subjects: Apparently healthy subjects aged 18-65 years (including young adult, mature adult and elderly populations) of both genders.

Results: The general prevalence (weighted mean) of MS in Latin-American countries was 24.9 (range: $18 \cdot 8-43 \cdot 3$ ) \%. MS was slightly more frequent in women $(25 \cdot 3 \%)$ than in men $(23 \cdot 2 \%)$, and the age group with the highest prevalence of MS consisted of those over 50 years of age. The most frequent components of MS were low HDL cholesterol levels (62.9\%) and abdominal obesity (45.8\%). Similar outcomes were obtained from the multi-centre study on Latin-American populations analysed.

Conclusions: The present review brings us closer to an understanding of the prevalence of MS in Latin-American countries. However, it is not possible to know the full scope of the problem, partly because data from some countries are not available, and because the methodological differences among the studies published up to the present limit a joint analysis of their results.
\end{abstract}

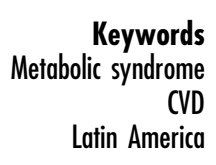

\section{A description of metabolic syndrome}

In 1998, Reaven ${ }^{(1)}$ defined metabolic syndrome (MS), also known as $\mathrm{X}$ syndrome, as a conglomerate of coronary risk factors. Since that time, the definition of MS has been modified by a number of experts ${ }^{(2-4)}$. Although the different definitions of MS generally include the same components, they differ in the assignment of each component's importance for the diagnosis of MS (for instance, number of criteria, hierarchy of components).
The definition provided by the Adult Treatment Panel III (ATP III) seems to be more 'equitable, (5), given that it does not establish a hierarchal relationship among the five components: abdominal obesity (AO), glucose alterations, hypertension (HT), hypertriacylglycerolaemia and low HDL cholesterol levels. In addition, ATP III is one of the most internationally accepted and used definitions, as well as the most up-to-date as a result of its high use and analysis $^{(3,6,7)}$. Nevertheless, it is worth mentioning that, in the latter part of 2009, prominent institutions such as the 
Table 1 ATP III criteria for clinical diagnosis of metabolic syndrome

\begin{tabular}{|c|c|}
\hline ATP III, $2001^{(6)}$ & ATP III, $2005^{(3)}$ \\
\hline $\begin{array}{l}\text { 1. Abdominal obesity - waist circumference }>102 \mathrm{~cm} \text { in men } \\
\text { and }>88 \mathrm{~cm} \text { in women (measured at the mid-point } \\
\text { between the lower-most rib and the iliac crest) }\end{array}$ & $\begin{array}{l}\text { 1. Abdominal obesity - waist circumference }>102 \mathrm{~cm} \text { in men } \\
\text { and }>88 \mathrm{~cm} \text { in women (measured at the mid-point } \\
\text { between the lower-most rib and the iliac crest) }\end{array}$ \\
\hline $\begin{array}{l}\text { 2. Elevated fasting glucose - fasting serum glucose } \\
\geq 110 \mathrm{mg} / \mathrm{dl}\end{array}$ & $\begin{array}{l}\text { 2. Elevated fasting glucose - fasting serum glucose } \\
\geq 100 \mathrm{mg} / \mathrm{dl} \text {, or on drug treatment for elevated glucose }\end{array}$ \\
\hline $\begin{array}{l}\text { 3. Hypertension - systolic blood pressure } \geq 130 \mathrm{mmHg} \text { and/ } \\
\text { or diastolic blood pressure } \geq 85 \mathrm{mmHg} \text {, or the current use } \\
\text { of anti-hypertensive medication }\end{array}$ & $\begin{array}{l}\text { 3. Hypertension - systolic blood pressure of } \geq 130 \mathrm{mmHg} \\
\text { and/or diastolic blood pressure } \geq 85 \mathrm{mmHg} \text {, or the current } \\
\text { use of anti-hypertensive medication }\end{array}$ \\
\hline $\begin{array}{l}\text { 4. Low HDL cholesterol - serum HDL cholesterol }<40 \mathrm{mg} / \mathrm{dl} \\
\text { in men and }<50 \mathrm{mg} / \mathrm{dl} \text { in women } \\
\text { 5. Hiah TAG - serum TAG } \geq 150 \mathrm{ma} / \mathrm{dl} \text {, in both genders }\end{array}$ & $\begin{array}{l}\text { 4. Low HDL cholesterol - serum HDL cholesterol }<40 \mathrm{mg} / \mathrm{dl} \\
\text { in men and }<50 \mathrm{mg} / \mathrm{dl} \text { in women, or on drug treatment for } \\
\text { reduced } \mathrm{HDL} \text { cholesterol }\end{array}$ \\
\hline & $\begin{array}{l}\text { 5. High TAG - serum TAG } \geq 150 \mathrm{mg} / \mathrm{dl} \text {, in both genders, or } \\
\text { on drug treatment for elevated TAG }\end{array}$ \\
\hline
\end{tabular}

ATP III, Adult Treatment Panel III.

International Diabetes Federation (IDF) and the American Heart Association/National Heart, Lung and Blood Institute standardized their criteria for defining $\mathrm{MS}^{(8)}$. These updated diagnostic criteria maintained the components defined by the last ATP III modification made in $2005^{(3)}$, and also contributed with new guidelines for the measurement of waist circumference by recommending specific cut-off points for each ethnic group or population (Table 1).

\section{Clinical importance of diagnosing metabolic syndrome}

In 2007, Grundy ${ }^{(9)}$ described the reasons why MS analysis was useful from a clinical perspective. To summarize, it mentions that MS detection is important because it allows for easy identification of patients who are at risk of developing atherosclerosis, type 2 diabetes mellitus and/or associated comorbidities and who are subjected to a higher risk of mortality from these causes ${ }^{(10-17)}$. In addition, the concept of MS facilitates the understanding of the physiopathological relationships between its different components and other related cardiovascular risk factors. This understanding may also be helpful for carrying out epidemiological and clinical studies associated with the treatment and/or prevention of CVD, which may entail drugs, lifestyle changes ${ }^{(9,11)}$ or both simultaneously.

\section{Prevalence of metabolic syndrome in the world}

The prevalence of MS is high in Europe and USA. In a compilation of observational studies conducted on people from a number of European countries (Switzerland, Spain, the Netherlands, Italy, France, the UK and Denmark), it was reported that non-diabetic subjects under 40 years of age had an MS prevalence of $14-41 \%$, depending on the age range $^{(18)}$. In Catalonia (Spain), Buckland et al. ${ }^{(19)}$ determined the prevalence of MS in people aged 18-74 years as $24 \cdot 8 \%$, ranging from $2 \cdot 5 \%$ (in 18-24-year-olds) to $51 \cdot 1 \%$ (in 65-74-year-olds). In the USA, an MS prevalence of
$21 \cdot 8 \%$ was found, which ranged from $6 \cdot 7 \%$ (in 20-29-yearolds) to $43.5 \%$ (in 60-69-year-olds) ${ }^{(20)}$.

Results from different cross-sectional studies conducted in countries with emerging economies have reported that the prevalence of MS in these countries is also high. Hence, in studies carried out on adult populations of India and Iran, the prevalence rates of MS varied from $33.7 \%$ to $41 \%{ }^{(21-23)}$.

Although there are several studies reporting the prevalence of MS in Latin America, in the majority of them MS is a secondary objective of the study and thus they do not reflect the real prevalence of this syndrome among the general population. This may be because this region has experienced a nutritional transition, having gone from being an area in which malnutrition was a main concern to experiencing problems associated with overeating (obesity, MS and CVD mortality). This situation has probably delayed the development of studies focusing exclusively on MS and its components, as well as the analysis of other precursors to the development of these diseases.

For these reasons, the objective of the present systematic review is to assess the prevalence of MS in Latin America using data already published in the scientific literature.

\section{Materials and methods}

\section{General features of searches}

Two electronic bibliographic indexes, one of which was discipline specific (PubMed) and another that was multidisciplinary (ISIWeb), were searched, along with two multidisciplinary databases for Ibero-America (SCielo and Redalyc). The terms used to describe MS were taken from the PubMed (MeSH) dictionary. The keywords used were 'metabolic syndrome x' (which also included 'insulin resistance syndrome x', 'dysmetabolic syndrome x', 'Reaven syndrome $\mathrm{x}$ ', 'metabolic cardiovascular syndrome') and 'prevalence', with their respective translations into Spanish. These terms were searched in titles and/or abstracts. 
Table 2 Flow chart for selection of articles for the present review

\section{Article selection criteria}

1. We reviewed 5216 studies on an individual basis and selected origina articles that presented information on MS prevalence in Latin-American countries. We began by reviewing titles and abstracts. When we were unable to obtain sufficient information from a particular title and abstract, we proceeded to check the full article. For the purposes of the present study, Latin America is considered to be the region of the Americas where Spanish, Portuguese and French are primarily spoken, including the Caribbean. The countries included are: Argentina, Bolivia, Brazil, Chile, Colombia, Costa Rica, Cuba, Ecuador, El Salvador, Guatemala, Haiti, Honduras, Mexico, Nicaragua, Panama, Paraguay, Peru, the Dominican Republic, Uruguay, Venezuela, Clipperton Island, Guadeloupe, French Guiana, Martinique, Saint Barthelemy, Saint Pierre and Miquelon, Puerto Rico

2. Main objective of the article focused on the study of MS prevalence

3. The study population comprised apparently healthy subjects, approximately 18-65 years of age (including young adult, mature adult and elderly population), of both sexes

\section{Clinical diagnosis of MS determined using ATP III criteria}

5. The available information was sufficient to accomplish the objectives of the present review

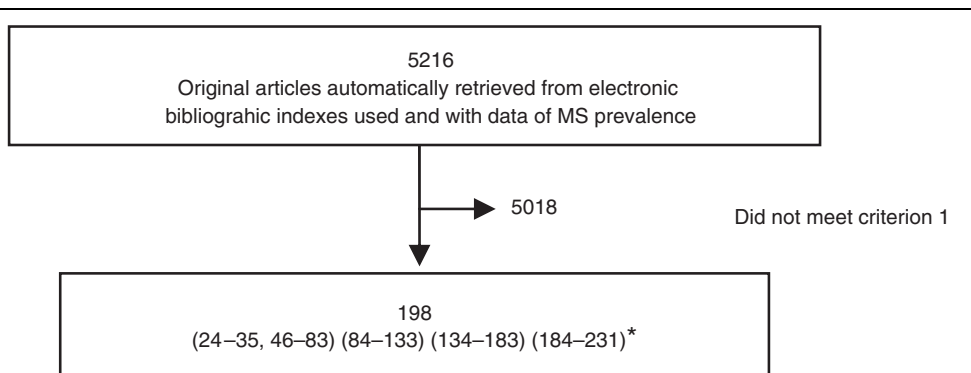

Did not meet criterion 2

$24-35,47-51,53-57,59,63,66,68-70,75,76,82,86,87,95,98,100,102,103,105-107,114-117,119,120,122,125,128)(130$, $131,134,136,137,140,143,144,146,147,150,152,156-159,161,163,167,169,173,177-180,184,188,189,192,193,195$, $200,201,206,208,209,219,221,227,231)^{*}$

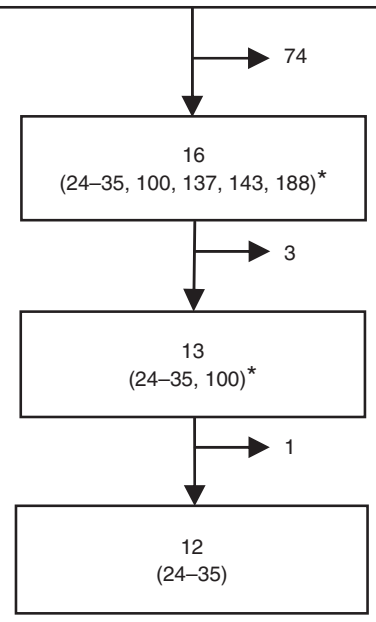

Did not meet criterion 3

Did not meet criterion 4

Did not meet criterion 5 
Searches were limited to articles published between January 2000 and March 2010.

\section{Selection of articles}

The criteria used and the selection process for the articles are shown in Table 2. A total of 5216 original cross-sectional studies containing data on the prevalence of MS were automatically identified by applying the afore-mentioned search terms. Among the latter, articles were chosen through a sequential application of our five criteria (see Table 2). Finally, a total of twelve articles met the criteria for the present review ${ }^{(24-35)}$. Of these articles (eleven crosssectional $^{(24-34)}$ and one multi-centre cross-sectional ${ }^{(35)}$; Tables 3 and 4 , respectively), the following data were found: author and year of publication, number and gender of participants, age range of the population, sampling, city and country in which the study was carried out, procedures to determine MS and its components (measurements), the prevalence of MS and its components, as well as other sociodemographic and environmental factors analysed as associations by the authors. In addition, the following variables were analysed: study design, prevalence of MS and its components by gender and age group, as well as adjusted MS prevalence.

The (weighted) mean prevalence rates found in the present review were calculated as follows: sum of the number of cases in all studies considered/sum of the number of participants in all studies considered $\times 100$.

\section{Results}

In the first part of this section, we summarize the results of the eleven cross-sectional studies selected for the present review (Table 3). In the last part of this section, the data reported by the CARMELA ${ }^{(35)}$ study are described, because it was the only cross-sectional multi-centre study that did not provide data on the prevalence of the different components of MS within the entire study population and reported only figures from the population that had MS (Table 4).

\section{Prevalence of metabolic syndrome}

The eleven studies included in this section encompassed $5635(40 \cdot 8 \%)$ men and $8173(59 \cdot 2 \%)$ women. In ten studies, the general prevalence of $\mathrm{MS}^{(24-30,32-34)}$ was reported, and in four of these the prevalence adjusted for age was presented ${ }^{(24,27,30,31,33)}$, whereas one presented prevalence adjusted for age and gender ${ }^{(25)}$. One study did not present general prevalence and only described prevalence adjusted for age ${ }^{(31)}$. In the studies that mentioned rates of prevalence, the weighted mean for MS general prevalence was $24 \cdot 9 \%^{(24-30,32-34)}$, the weighted mean for age-adjusted prevalence was $28 \cdot 03 \%^{(24,27,30,31,33)}$ and the weighted mean for age- and gender-adjusted prevalence was $29.5 \%{ }^{(25)}$.
MS was most prevalent in the city of San Juan $(43 \cdot 3 \%)^{(24)}$, in a study carried out on the general population. The city that reported the lowest prevalence of MS was Arequipa, among a mestizo population $(18 \cdot 8 \%)^{(27)}$.

Nine articles reported the prevalence of MS by gen$\operatorname{der}^{(24,25,27-31,33,34)}$ : weighted mean was $25 \cdot 3 \%$ for women and $23 \cdot 2 \%$ for men; differences were not statistically significant. In three studies ${ }^{(27,28,34)}$ (two of which had higher participation by women ${ }^{(27,34)}$, whereas one had higher participation by men ${ }^{(28)}$ ), MS was slightly more frequent among women compared with men, with a difference in prevalence between men and women varying between $0 \cdot 8 \%^{(34)}$ and $8 \cdot 89 \%{ }^{(27)}$. Furthermore, in the study conducted on the population of Minas Gerais $^{(33)}$, which contained a higher proportion of women, this difference in prevalence was $25.9 \%$ (33.6\% for women and $7 \cdot 7 \%$ for men). However, in four other studies ${ }^{(24,25,30,31)}$, the prevalence of MS was slightly higher in men than in women: the differences varied between $1 \cdot 1 \%{ }^{(25)}$ and $5 \cdot 2 \%{ }^{(30)}$. Likewise, in the study carried out on the population of San Juan ${ }^{(29)}$, a higher prevalence was reported for men (41\%) than for women (26\%).

Nine studies reported prevalence by age $\mathrm{e}^{(24,27-34)}$. In six of these $\mathrm{e}^{(24,27,28,32-34)}$, the prevalence of MS was observed to increase with age, whereas in the other three studies this was not the case $\mathrm{e}^{(29-31)}$. The highest prevalence of MS was observed in subjects older than 50 years of age, with the exception of Mexico, in which the population with the highest prevalence $(27 \cdot 5 \%)$ was that of 30 -39-year-olds ${ }^{(31)}$. By contrast, the lowest prevalence was generally observed in those under the age of 30 years, with the exception of Mexico, where the lowest prevalence $(8 \cdot 7 \%)$ was found to be among the 60-69-year-old population ${ }^{(31)}$.

\section{Prevalence of the components of metabolic syndrome}

The prevalence of the components of MS among the populations analysed varied greatly from one country to another (Table 3). The weighted mean prevalence (range) by component was as follows: low HDL cholesterol, $62 \cdot 9\left(21 \cdot 5^{(25)}-96 \cdot 1^{(26)}\right) \%$; hypertriacylglycerolaemia, $46 \cdot 7$ $\left(22 \cdot 3^{(33)}-87 \cdot 3^{(27)}\right) \% ;$ AO, $45 \cdot 8\left(26 \cdot 7^{(33)}-53 \cdot 6^{(26)}\right) \%$; HT, $42 \cdot 6\left(16 \cdot 8^{(26)}-77 \cdot 2^{(29)}\right) \%$; and abnormal blood glucose, $17 \cdot 6\left(3 \cdot 9^{(26)}-49 \cdot 8^{(24)}\right) \%$. For abnormal blood glucose and dyslipidaemia, none of the studies stated how many subjects were diagnosed because they were being treated or because of concentrations in blood samples (as suggested by ATP III 2005 criteria $^{(3)}$ ).

The prevalence of components by gender and age group were not reported in any of the articles. Only seven studies described the presence of MS components by gender ${ }^{(24,26,27,29,30,32,33)}$. In addition, three studies reported the prevalence of each of the MS components by age group $^{(27,29,32)}$ and another reported these data by age, but only for $\mathrm{AO}^{(28)}$. In general, a higher prevalence of these components was found in populations older than 49 years, 
Table 3 Cross-sectional studies of the prevalence of MS among Latin-American populations included in the present review

\begin{tabular}{|c|c|c|c|c|c|c|c|}
\hline Author & Population study & City/country & Sampling & Measurements & $\begin{array}{c}\text { Overall } \\
\text { prevalence } \\
\text { of MS }(\%)\end{array}$ & $\begin{array}{c}\text { Overall prevalence of } \\
\text { individual components } \\
\text { of MS }(\%)\end{array}$ & Associations* \\
\hline Pérez et al. ${ }^{(24)}$ & $\begin{array}{l}867 \text { adults, } \\
21-79 \text { years old } \\
66 \% \mathrm{~W}, 34 \% \mathrm{M}\end{array}$ & $\begin{array}{l}\text { San Juan, } \\
\text { Puerto Rico }\end{array}$ & $\begin{array}{l}\text { Probabilistic, } \\
\text { without specifying } \\
\text { the exact type }\end{array}$ & $\begin{array}{l}\text { WC: at the highest point } \\
\text { of the iliac crest, with } \\
\text { minimal breathing } \\
\text { G, TAG and HDL-C: fasting } \\
\text { BP: three measurements } \\
\text { MS: ATP III, } 2005\end{array}$ & $43 \cdot 3$ & $\begin{array}{l}\text { AO: } 49 \\
\text { High G: } 49 \cdot 8 \\
\text { HT: } 46 \cdot 1 \\
\text { High TAG: } 31 \cdot 1 \\
\text { Low HDL-C: } 46\end{array}$ & $\mathrm{~N} / \mathrm{A}$ \\
\hline Mujica et al. ${ }^{(25)}$ & $\begin{array}{l}1007 \text { adults, } \\
18-74 \text { years old } \\
66 \% \mathrm{~W}, 34 \% \mathrm{M}\end{array}$ & Talca, Chile & $\begin{array}{l}\text { Probabilistic, } \\
\text { without specifying } \\
\text { the exact type }\end{array}$ & $\begin{array}{l}\text { WC: N/A } \\
\text { G, TAG and HDL-C: fasting } \\
\text { BP: N/A } \\
\text { MS: ATP III, } 2005\end{array}$ & $35 \cdot 5$ & $\begin{array}{l}\text { AO: N/A } \\
\text { High G: } 26 \cdot 3 \\
\text { HT: } 37 \cdot 0 \\
\text { High TAG: } 40 \cdot 1 \\
\text { Low HDL-C: } 21 \cdot 5\end{array}$ & $\mathrm{~N} / \mathrm{A}$ \\
\hline Pinzón et al. ${ }^{(26)}$ & $\begin{array}{l}155 \text { adults, } \\
22-73 \text { years old } \\
46 \% \mathrm{~W}, 54 \% \mathrm{M}\end{array}$ & $\begin{array}{l}\text { Bucaramanga, } \\
\text { Colombia }\end{array}$ & Convenience & $\begin{array}{l}\text { WC: NHANES II } \\
\text { G, TAG and HDL-C: fasting } \\
\text { BP: American Society of } \\
\text { HT } \\
\text { MS: ATP III, } 2005\end{array}$ & $34 \cdot 8$ & $\begin{array}{l}\text { AO: } 53 \cdot 6 \\
\text { High G: } 3 \cdot 9 \\
\text { High TAG: } 32 \cdot 9 \\
\text { HT: } 16 \cdot 8 \\
\text { Low HDL-C: } 96 \cdot 1\end{array}$ & $\mathrm{~N} / \mathrm{A}$ \\
\hline Medina et al. ${ }^{(27)}$ & $\begin{array}{l}1878 \text { adults, } \\
20-80 \text { years old } \\
54 \% \mathrm{~W}, 46 \% \mathrm{M}\end{array}$ & Arequipa, Peru & $\begin{array}{l}\text { Stratified and } \\
\text { randomized }\end{array}$ & $\begin{array}{l}\text { WC: at the navel level, after } \\
\text { exhaling normally } \\
\text { G, TAG and HDL-C: fasting } \\
\text { BP: Joint National } \\
\text { Committee } \\
\text { MS: ATP III, } 2005\end{array}$ & $18 \cdot 8$ & $\begin{array}{l}\text { AO: } 50 \cdot 9 \\
\text { High G: } 10 \cdot 4 \\
\text { HT: } 47 \cdot 0 \\
\text { High TAG: } 87 \cdot 3 \\
\text { Low HDL-C: } 93 \cdot 4\end{array}$ & $\begin{array}{l}\text { Logistic regression model } \\
\text { adjusted for age and sex: } \\
\text { Low physical activity: OR }=1 \cdot 92 \text {, } \\
95 \% \mathrm{Cl} 1 \cdot 41,2 \cdot 60 \\
\text { Excessive alcohol intake: } \\
\text { OR }=1 \cdot 59,95 \% \mathrm{Cl} 1 \cdot 06,2 \cdot 40 \\
\text { Familial antecedent of } \\
\text { hypertension and type } 2 \\
\text { diabetes: OR }=1 \cdot 63,95 \% \mathrm{Cl} \\
1 \cdot 23,2 \cdot 16 \text { and OR }=1 \cdot 66, \\
95 \% \mathrm{Cl} 1 \cdot 17,2 \cdot 33 \text {, respectively }\end{array}$ \\
\hline Tull et al. ${ }^{(28)}$ & $\begin{array}{l}893 \text { adults, } \\
20-70 \text { years old } \\
46 \% \mathrm{~W}, 54 \% \mathrm{M}\end{array}$ & $\begin{array}{l}\text { Saint Croix, Virgin } \\
\text { Islands }\end{array}$ & $\begin{array}{l}\text { Probabilistic, } \\
\text { without specifying } \\
\text { the exact type }\end{array}$ & $\begin{array}{l}\text { WC: N/A } \\
\text { BP: one measurement. } \\
\text { G, TAG and HDL-C: fasting } \\
\text { MS: ATP III, } 2001\end{array}$ & $20 \cdot 5 t$ & $\begin{array}{l}\text { AO: N/A } \\
\text { HT: N/A } \\
\text { High G: N/A } \\
\text { High TAG: N/A } \\
\text { Low HDL-C: N/A }\end{array}$ & $\begin{array}{l}\text { Logistic regression model: } \\
\geq 70 \text { years: OR }=1 \cdot 04,95 \% \mathrm{Cl} \\
1 \cdot 02,1 \cdot 05 \\
\text { Hispanic: } \mathrm{OR}=1 \cdot 82,95 \% \mathrm{Cl} \\
\text { 1.07, } 3 \cdot 07 \\
\text { HOMA-IR score: OR }=5 \cdot 59 \\
95 \% \mathrm{Cl} 3 \cdot 69,8 \cdot 46\end{array}$ \\
\hline
\end{tabular}


Table 3 Continued

\begin{tabular}{|c|c|c|c|c|}
\hline Author & Population study & City/country & Sampling & Measurements \\
\hline Gómez et al. ${ }^{(29)}$ & $\begin{array}{l}202 \text { adults, } \\
\geq 20 \text { years old } \\
60 \% \mathrm{~W}, 40 \% \mathrm{M}\end{array}$ & $\begin{array}{l}\text { San Juan, Puerto } \\
\text { Rico }\end{array}$ & Convenience & $\begin{array}{l}\text { WC: N/A } \\
\text { G, TAG and HDL-C: N/A } \\
\text { BP: N/A } \\
\text { MS: ATP III, } 2001\end{array}$ \\
\hline Florez et al. ${ }^{(30)}$ & $\begin{array}{l}3108 \text { adults, } \\
\geq 20 \text { years old }\end{array}$ & Zulia, Venezuela & $\begin{array}{l}\text { Stratified and } \\
\text { randomized }\end{array}$ & $\begin{array}{l}\text { WC: at the navel level } \\
\text { G, TAG and HDL-C: fasting } \\
\text { BP: two measurements } \\
\text { MS: ATP III, } 2001\end{array}$ \\
\hline
\end{tabular}

\section{Aguilar et al. ${ }^{(31)} \quad 2158$ adults, Mexico}

20-69 years old

$\begin{array}{ccc}\text { Marquezine et al. }{ }^{(32)} \begin{array}{c}1507 \text { adults, } \\ 25-64 \text { years old }\end{array} & \text { Victoria, Brazil } \\ & & \\ & & \\ \text { Velásquez et al. }{ }^{(33)} & \begin{array}{c}251 \text { adults, } \\ 18-88 \text { years old } \\ 47 \% \text { W, } 53 \% \mathrm{M}\end{array} & \begin{array}{c}\text { Virgem das } \\ \text { Graças, Minas } \\ \text { Gerais, Brazil }\end{array}\end{array}$
Probabilistic, without WC: replaced by BMI specifying the exact type
G, TAG and HDL-C: fasting
BP: two measurements
MS: ATP III, 2001
Probabilistic, without specifying the exact type

WC: at the mid-point between the lower-mos rib and the iliac crest G, TAG and HDL-C: fasting BP: one measurement MS: ATP III, 2001

N/A $47 \%$ W, $53 \%$ M
Graças, Minas

\section{Overall}

of MS (\%)

Overall prevalence of
WC: at the mid-point between the lower-most rib and the iliac crest
G, TAG and HDL-C: fasting $B P$ : thre MS: ATP III, 2001

$\quad$ of MS $(\%)$
AO: $48 \cdot 5$
High G: $31 \cdot 2$
HT: $77 \cdot 2$
High TAG: $31 \cdot 2$
Low HDL-C: $27 \cdot 7$
AO: $42 \cdot 9$
High G: $10 \cdot 9$
HT: $38 \cdot 1$
High TAG: $32 \cdot 3$
Low HDL-C: $65 \cdot 3$

Associations*

Logistic regression model:

Age $>45$ years: $\mathrm{OR}=3 \cdot 82,95 \%$ $\mathrm{Cl} 3.01,4.84$

Sedentary: $\mathrm{OR}=1 \cdot 39,95 \% \mathrm{Cl}$ $1 \cdot 01,1 \cdot 91$

Low HDL-C: $65 \cdot 3$

Cl $3 \cdot 25,5 \cdot 54$

High HOMA-IR score: OR $=2.44$ $95 \% \mathrm{Cl} 1.93,3.09$

$26 \cdot 6$

AO: N/A

N/A

High G: N/A

HT: N/A

High TAG: N/A

Low HDL-C: N/A

$25 \cdot 4$

AO: N/A
High G: N/A
HT: N/A
High TAG: N/A

Low HDL-C: N/A

$21 \cdot 6$

AO: $26 \cdot 7$

High G: $6 \cdot 0$

High TAG: $22 \cdot 3$

HT: $62 \cdot 5$

Low HDL-C: $37 \cdot 1$
Low-income social class: $\mathrm{OR}=1 \cdot 64$

Logistic regression model: $\mathrm{BMI}>25 \mathrm{~kg} / \mathrm{m}^{2}: \mathrm{OR}=20 \cdot 84$, $95 \%$ Cl 8.85, 49.09 Age 30-42 yearsł: OR $=3.38$, $95 \% \mathrm{Cl} 1 \cdot 22,9 \cdot 36$ Age 43-59 years: OR $=5.89$, $95 \% \mathrm{Cl} 1 \cdot 82,9.04$ Age 60-88 years: $\mathrm{OR}=20 \cdot 75$, $95 \% \mathrm{Cl} 4 \cdot 98,86 \cdot 47$ 


\begin{tabular}{|c|c|c|c|c|c|c|c|}
\hline Author & Population study & City/country & Sampling & Measurements & $\begin{array}{l}\text { Overall } \\
\text { prevalence } \\
\text { of MS }(\%)\end{array}$ & $\begin{array}{c}\text { Overall prevalence of } \\
\text { individual components } \\
\text { of MS (\%) }\end{array}$ & Associations \\
\hline Salaroli et al. ${ }^{(34)}$ & $\begin{array}{l}1630 \text { adults, 25-64 } \\
\text { years old } \\
54 \% \mathrm{~W}, 46 \% \mathrm{M}\end{array}$ & Victoria, Brazil & $\begin{array}{l}\text { Stratified and } \\
\text { randomized }\end{array}$ & $\begin{array}{l}\text { WC: the lesser curvature, } \\
\text { between the lower-most } \\
\text { rib and the iliac crest } \\
\text { G, TAG and HDL-C: fasting } \\
\text { BP: two measurements } \\
\text { MS: ATP III, } 2001\end{array}$ & $29 \cdot 8$ & $\begin{array}{l}\text { AO: N/A } \\
\text { High G: N/A } \\
\text { HT: N/A } \\
\text { Hypertriglyceridaemia: } \\
\text { N/A } \\
\text { Low HDL-C: N/A }\end{array}$ & $\mathrm{N} / \mathrm{A}$ \\
\hline
\end{tabular}

MS, metabolic syndrome; W, women; M, men; WC, waist circumference; G, glucose; HDL-C, HDL cholesterol; BP, blood pressure; ATP III, Adult Treatment Panel III; N/A, information not available; NHANES II, Second National Health and Nutrition Examination Survey; AO, abdominal obesity; high G, hyperglycaemia; HT, hypertension; high TAG, hypertriacylglycerolaemia; HOMA-IR, homeostatic model assessment-insulin resistance. *Only statistically significant associations are shown $(P<0 \cdot 05)$.

.

fReference group for age $<30$ years.

Table 4 Cross-sectional multi-centre study of the prevalence of MS among Latin-American populations included in the present review

\begin{tabular}{|c|c|c|c|c|c|c|c|}
\hline Author & Population study (n) & Countries & Sampling & Measurements & $\begin{array}{c}\text { Overall prevalence } \\
\text { of MS (\%) }\end{array}$ & $\begin{array}{c}\text { Overall prevalence of } \\
\text { individual components of } \\
\text { MS }(\%)^{*}\end{array}$ & Associations \\
\hline $\begin{array}{l}\text { Escobedo } \\
\text { et al. }{ }^{(35)}\end{array}$ & $\begin{array}{l}11550 \text { adults, } \\
25-64 \text { years old } \\
50 \% \mathrm{~W}, 50 \% \mathrm{M}\end{array}$ & $\begin{array}{l}\text { Barquisimeto, Venezuela } \\
(n 1836) \\
\text { Bogota, Colombia ( } n \text { 1550) } \\
\text { Buenos Aires, Argentina } \\
(n \text { 1476) } \\
\text { Lima, Peru ( } n \text { 1645) } \\
\text { Mexico City, Mexico } \\
\quad(n \text { 1720) } \\
\text { Quito, Ecuador ( } n \text { 1627) } \\
\text { Santiago, Chile ( } n \text { 1648) }\end{array}$ & $\begin{array}{l}\text { Stratified and } \\
\text { randomized }\end{array}$ & $\begin{array}{l}\text { WC: at the mid-point } \\
\text { between the lower-most } \\
\text { rib and the iliac crest } \\
\text { G, TAG and HDL-C: fasting } \\
\text { BP: two measurements } \\
\text { MS: ATP III, } 2001\end{array}$ & $\begin{array}{l}\text { Barquisimeto: } 26 \\
\text { Bogota: } 20 \\
\text { Lima: } 18 \\
\text { Mexico City: } 27 \\
\text { Buenos Aires: } 17 \\
\text { Quito: } 14 \\
\text { Santiago: } 21\end{array}$ & $\begin{array}{l}\text { AO: } 76 \cdot 3 \\
\text { High G: } 31 \cdot 2 \\
\text { HT: } 60 \cdot 1 \\
\text { High TAG: } 85 \cdot 9 \\
\text { Low HDL-C: } 85 \cdot 6\end{array}$ & $\mathrm{~N} / \mathrm{A}$ \\
\hline
\end{tabular}


whereas the lower prevalence was found in those under 34 years of age, except for low HDL cholesterol levels.

\section{Abdominal obesity}

The prevalence of $\mathrm{AO}$ was reported in six stu$\operatorname{dies}^{(24,26,27,29,30,33)}$. The weighted mean prevalence was $45 \cdot 8 \%$. AO was shown to be the most prevalent among employees (medical school) in Colombia $(53 \cdot 6 \%)^{(26)}$. The smallest prevalence of $\mathrm{AO}$ was found among the black and mestizo population (26.7\%) of Minas Gerais ${ }^{(33)}$.

In six studies, the prevalence of $\mathrm{AO}$ was reported by gender ${ }^{(24,26,27,30,32,33)}$, with a mean prevalence of $41.6 \%$ for women and $21.7 \%$ for men. In five of them, the prevalence was higher for women than for $\operatorname{men}^{(24,27,30,32,33)}$. Differences in prevalence for women and men varied between $14 \cdot 4 \%^{(32)}$ and $23 \cdot 0 \%{ }^{(27)}$, with the exception of one study in which the difference was $42 \cdot 0 \%(46 \cdot 3 \% \text { for women and } 4.3 \% \text { for men })^{(36)}$. By contrast, in the study by Pinzón et al. ${ }^{(26)}$, a higher prevalence was reported for men $(75.0 \%)$ than for women (28.2\%). In four studies the prevalence of $\mathrm{AO}$ was reported by age groups ${ }^{(27-29,32)}$. In three of them, the prevalence of $\mathrm{AO}$ increased with age $\mathrm{e}^{(27,29,32)}$.

\section{Abnormal glycaemia}

Seven studies mentioned the prevalence of abnormal glycaemia (AG) $)^{(24-27,29,30,33)}$ among the population. In these seven studies, the weighted mean prevalence of AG was $17 \cdot 6 \%$. AG had the higher prevalence in the city of San Juan, in the general population (49.8\%) ${ }^{(24)}$ and in university employees $(31 \cdot 2 \%)^{(29)}$. The lowest prevalence of AG was found among employees in Bucaramanga (3.9\%) ${ }^{(26)}$.

In six studies, the prevalence of AG was described by gender $^{(24,26,27,30,32,33)}$ (weighted mean was $14 \cdot 3 \%$ for women and $17 \cdot 6 \%$ for men). In one of these, the prevalence was higher in women than in men, with a difference of $1 \cdot 6 \%{ }^{(33)}$. In the other five studies ${ }^{(24,26,27,30,32)}$, the prevalence was higher in men than in women, with differences between $0 \cdot 4 \%{ }^{(27)}$ and $16 \cdot 7 \%^{(24)}$. Only three studies reported the prevalence of AG by age ${ }^{(27,29,32)}$, observing an increase with age.

\section{Hypertension}

The weighted mean prevalence of HT was found to be $42.6 \%$ in the seven studies that reported on the general prevalence of this component ${ }^{(24-27,29,30,33)}$. HT was most prevalent in San Juan $(77 \cdot 2 \%)^{(29)}$ and the lowest prevalence was, again, in Bucaramanga $(16 \cdot 8 \%)^{(26)}$, both studies conducted among university employees.

Six studies reported the prevalence of HT by gen$\operatorname{der}^{(24,26,27,30,32,33)}$ (weighted mean was $40 \cdot 2 \%$ for women, $38.4 \%$ for men). In one of them, the prevalence was higher for women $(47.9 \%)$ than for men $(31.4 \%)^{(30)}$. In the remaining studies ${ }^{(24,26,27,30,32,33)}$, the prevalence was higher for men than for women, with the reported differences ranging from $3 \cdot 8 \%{ }^{(27)}$ to $18 \cdot 0 \%{ }^{(26)}$. Only three studies reported the prevalence of HT by age ${ }^{(27,29,32)}$, observing an increase in parallel.

\section{Dyslipidaemia}

The same seven studies mentioned the general prevalence of dyslipidaemia ${ }^{(24-27,29,30,33)}$; the weighted mean of hypertriacylglycerolaemia was $46.7 \%$, and for low levels of HDL cholesterol the weighted mean was $62.9 \%$.

Hypertriacylglycerolaemia was most prevalent among the general population of the city of Arequipa $(87 \cdot 3 \%)^{(27)}$. On the other hand, the lowest prevalence of hypertriacylglycerolaemia was found in Minas Gerais, among the general population $(22 \cdot 3 \%)^{(33)}$. In five of the six studies that reported the prevalence of hypertriacylglycerolaemia by gender ${ }^{(24,26,27,30,32)}$, it was more prevalent in men than in women, with differences between $12 \cdot 9 \%{ }^{(24)}$ and $16 \cdot 7 \%{ }^{(27)}$, except in one study, in which the difference was $42.5 \%{ }^{(26)}$. In the study by Velasquez-Melendez et $a l^{(33)}$, the prevalence was slightly higher among women (23.9\%) than among men (20.5\%). The weighted mean prevalence of hypertriacylglycerolaemia was $28.1 \%$ for women and $43.6 \%$ for men.

Low levels of HDL cholesterol were most prevalent among university employees in Bucaramanga $(96 \cdot 1 \%)^{(26)}$, and least prevalent in Talca (general Chilean population, $21.5 \%)^{(25)}$. In the six studies that reported on the prevalence

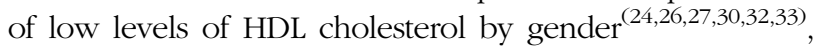
a higher prevalence was observed among women than among men (with differences between $2 \cdot 0 \%{ }^{(26)}$ and $\left.28 \cdot 4 \%{ }^{(27)}\right)$. The weighted mean prevalence by gender was $63 \%$ for women and $45.8 \%$ for men.

Three studies reported on the prevalence of dyslipidaemia by age group ${ }^{(27,29,32)}$, observing an increase by age. With regard to low HDL cholesterol levels, the prevalence of low HDL cholesterol levels decreased when age increased ${ }^{(27,29)}$ : it was least frequent among individuals older than 49 years of age and most frequent among those under the age of 34 years. One study did not point to a clear trend by age ${ }^{(32)}$.

\section{Factors associated with metabolic syndrome}

Six studies analysed the possible associations between different risk factors and the presence of $\mathrm{MS}^{(27,28,30,32-34)}$. The risk of MS increased significantly with age and with the presence of various conditions such as being Hispanic or indigenous, belonging to a low-income class, insufficient physical activity, excessive alcohol consumption, smoking and a history of HT and of type 2 diabetes in first-degree family members (Table 3). The strongest association was observed with age in the case of adults aged between 60 and 88 years compared with those under $30(\mathrm{OR}=20 \cdot 75,95 \% \text { CI } 4 \cdot 98,86 \cdot 47)^{(33)}$. Insufficient physical activity (sedentary lifestyle) was the second most strongly associated risk factor $(\mathrm{OR}=1.92,95 \% \mathrm{CI}$ $1 \cdot 41,2 \cdot 60)^{(27)}$, followed by being Hispanic $(\mathrm{OR}=1 \cdot 82$, $95 \%$ CI $1 \cdot 07,3 \cdot 07)^{(28)}$. 
No statistically significant protective factors were reported in the studies included in the present review.

\section{The CARMELA study}

The CARMELA study is the only multi-centre crosssectional research aiming to assess cardiovascular risk factors in Latin-American populations ${ }^{(35)}$ (Table 4). The study included a total of 11502 individuals, with the same ratio of men and women, who were between 25 and 64 years of age and from urban populations of seven cities. The study population was selected by stratified random sample, and measurements were taken using the same protocol in each city. The 2001 ATP III criteria for diagnosing MS were used.

The highest prevalence of MS (27\%) was found in Mexico City, whereas the lowest (14\%) was found in Quito. The average prevalence in the total population was slightly higher for women than for men (22\% v. 20\%, respectively), with the exception of two cities, Buenos Aires and Barquisimeto, where men presented a higher prevalence of MS than did women. The prevalence of MS increased with age.

With respect to the components of MS, the CARMELA study only reported their prevalence among the population that presented MS and not among the total population. Thus, the most prevalent component of these subjects with MS was hypertriacylglycerolaemia (85.9\%), and the least frequent was abnormal glucose levels (31.2\%; Table 4). With regard to gender, the AO and low HDL cholesterol MS components were more frequent in women than in men, with gender differences reported to be $26 \cdot 8 \%$ and $5 \cdot 2 \%$, respectively. The remaining altered components were more prevalent in men than in women. The difference in prevalence between men and women was $14 \cdot 2 \%$ for HT, $7 \cdot 6 \%$ for hypertriacylglycerolaemia and $2.5 \%$ for abnormal glucose levels. The prevalence of MS components by age group was not reported in the CARMELA study.

\section{Discussion}

The present review provides an overall picture of the presence of MS in Latin America. According to data reviewed, the weighted mean prevalence of MS in the Latin-American countries analysed (24.9\%) was higher than that reported in developed countries ${ }^{(19,20)}$. In fact, in eight of the studies included in this analysis ${ }^{(24-26,29-32,34)}$, prevalence rates of MS are different in 1.5-20.0\% compared with those reported in the USA (21.8\%) and some European countries: Spain (24.7\%), Portugal (23.9\%) and Italy $(24 \cdot 1 \%)^{(18,19,20,36,37)}$. However, this mean prevalence of MS in Latin America was lower than that reported for some ethnic groups in other parts of the world. MS prevalence among Mexican Americans has been reported at $31.9 \%{ }^{(20)}$, whereas this figure has been reported at $35.5 \%$ for African or Afro-American people, $32 \cdot 8 \%$ for
Amerindians $^{(30)}, 31 \%$ for Yaquis Indians ${ }^{(38)}$ and $44 \%$ for Australian Aborigines ${ }^{(39)}$.

In our results, the most frequent component of MS was low HDL cholesterol $(62.9 \%)$, which suggests the need for monitoring it during medical check-ups, because in some Latin-American countries it is common to check only total cholesterol. In other studies, the most prevalent component was AO: $38 \cdot 6 \%$ in the $\mathrm{USA}^{(20)}$ and $60 \cdot 3 \%$ in Spain ${ }^{(19)}$. The high prevalence of low HDL cholesterol observed was higher than that reported for indigenous people in Mexico (34.2\%) and for Yaquis Indians $(42 \cdot 4 \%)^{(40)}$. In contrast, excess weight and obesity are more frequently reported in various ethnic groups: Yaquis Indians $(86 \cdot 7 \%)$ and Pima Indians $(90 \cdot 4 \%)^{(41,42)}$.

Differences in MS prevalence as high as 24.5 (range: 18.8-43.3)\% among Latin-American countries were observed in the studies analysed in the present review $^{(24,27)}$. The differences were even greater with respect to the prevalence of the components of MS. This might be explained, at least to some degree, by genetic, environmental and sociodemographic factors in the countries and/or their populations. However, the results of the present review do not make it possible to know the full scope of the problem because data from some countries are not available, and because the methodological differences among the studies published up to the present limit the overall analysis of their results.

One factor that makes comparability among studies difficult is the source and type of individuals studied. Thus, for instance, the population studied was mostly urban, and only in one article was a rural population studied $^{(33)}$. Nine studies included samples of the general population $^{(24,25,27,28,30,31,33-35)}$, and the rest included apparently healthy sample populations with particular features: university employees ${ }^{(26,29)}$ or a majority of mulatto subjects $^{(32)}$. In eight studies ${ }^{(24,25,27,29-32,34)}$, the presence of women was higher than that of men; in three ${ }^{(26,28,33)}$, the presence of men was higher; and in the multi-centre study $^{(35)}$, the percentages of women and men who took part were the same. In nine studies, the sample included the same number of individuals from each age group studied. In the other three studies ${ }^{(24,27,31)}$, a different number of individuals from different age groups was included (populations with the highest number of participants were in the age ranges of $30-39^{(31)}$ and $50-59$ years ${ }^{(24,27)}$ ).

Another limitation that makes comparability among studies difficult is the different methods used. The type of sampling was different among the studies selected (Tables 3 and 4). In order to diagnose MS, the majority (eight) of studies used the ATP III 2001 criteria $^{(28-35)}$; three were based on the ATP III 2005 criteria $^{(24,25,27)}$ and one was based on both ${ }^{(26)}$ (Table 1). Two studies, in addition to the diagnosis of MS by ATP III criteria, also used IDF criteria $^{(25,26)}$. Waist circumference was also not measured by the same method in all studies. In three of them, the method was not stated ${ }^{(25,28,29)}$; in three other 
studies, measurements were taken at the mid-point between the lower-most rib and the iliac crest $^{(32,33,35)}$. The remainder (six studies) used other techniques: the lesser curvature between the lower-most rib and the iliac crest $^{(34)}$; at the navel level ${ }^{(30)}$; at the navel level after exhaling normally ${ }^{(27)}$; at the highest point of the iliac crest with minimal breathing ${ }^{(24)}$; and in accordance with the protocol of the Second National Health and Nutrition Examination Survey ${ }^{(26)}$ or by replacing this variable with BMI measurements ${ }^{(31)}$. Furthermore, for blood pressure measurement, different techniques and instruments were used. A mercury sphygmomanometer was used in six studies $^{(27,28,32-35)}$; in another study, a standard aneroid sphygmomanometer was used ${ }^{(24)}$; in the rest, the type of instrument used is not mentioned ${ }^{(25,26,29-31)}$. Seven studies specify the number of measurements carried out (either one ${ }^{(28,32)}$, two ${ }^{(30,31,34)}$ or three ${ }^{(24,33)}$ ) (Table 3). The majority stated that, before carrying out the first, or the only, measurement, the patient rested in a sitting position for $5 \min ^{(24,28,30-32,34)}$. When the second or third blood pressure measurement was taken, the subject rested for between $2^{(33)}$ and $30 \mathrm{~min}^{(34)}$. Some studies took the average of the measurements as the value for blood pressure $^{(30,34)}$. Studies by Pinzón et al. ${ }^{(26)}$ and Medina et al. ${ }^{(27)}$ used the protocols established by the American Society of Hypertension and the Joint National Committee on Prevention, Detection, Evaluation, and Treatment of High Blood Pressure, respectively. Two articles gave no detailed explanation of how blood pressure was determined ${ }^{(25,29)}$.

A few of the analysed studies described environmental factors associated with the development of MS. It is beneficial to have this information, especially for potentially modifiable factors such as diet and physical activity. Nevertheless, this was not the main objective of the present review, which means that there may be other articles that provide more information on the topic, and hence another systematic review may be called for to examine this topic in more depth.

Morbidity and mortality trends in Latin America have changed in recent decades because of shifts in nutrition and lifestyle habits among the population. Urbanization and technology have transformed work, transportation and lifestyle behaviours, leading to a reduction in daily physical activity. There has also been a rise in the distribution of processed (energy dense) foods, which has had adverse effects on dietary patterns ${ }^{(43)}$. As a result of these factors, the region has gone from being one in which malnutrition was the main concern to one in which cardiovascular and chronic degenerative diseases are now the leading cause of death, as has been the case in developed countries ${ }^{(44)}$. It is therefore important to increase knowledge about MS and its determinants, as such knowledge could hasten the implementation of measures to reduce the prevalence of MS and its components, which could otherwise continue their upward trend in parallel with cardiovascular mortality ${ }^{(45)}$.

\section{Conclusion}

To our knowledge, this is the first systematic review of the prevalence of MS among different populations in Latin America. Our data suggest the need for multi-centre studies using current criteria that define $\mathrm{MS}^{(8)}$ and standardized methods that may make it possible to determine the precise scope of this problem among Latin-American populations. It is also essential to explore possible environmental factors, especially those related to lifestyle. Knowledge of these factors may be helpful in the monitoring of MS and could contribute to planning and prevention strategies to combat this condition, which is associated with a high risk of mortality and increased health-care costs for Latin-American governments and populations. Hence, all efforts to enhance knowledge of and deal better with MS are definitively justified.

\section{Acknowledgements}

F.M.-S. obtained a government grant from the CONACYT (Apoyos complementarios para el fortalecimiento de Cuerpos Académicos, modalidad repatriación 2009) programme. G.M.-O. received a scholarship student in a doctoral programme of recognized quality (beca nacional de CONACYT). D.V.-H., a student of Bachelor's degree in Nutrition, received a 6-month PRO-SNI grant from Universidad de Guadalajara. The authors have no conflict of interest to declare. B.V. and F.M.-S. directed the present study; B.V., J.S.-S. and J.F.-B. contributed to the study concept and design; F.M.-S., G.M.-O. and D.V.-H. helped with article searches, review and selection; F.M.-S., G.M.-O. and B.V. contributed to the analysis and interpretation of data and drafting of the manuscript; J.F.-B. and J.S.-S. worked as methodological advisors. All the authors contributed equally to the critical revision of the manuscript. The present paper is the first fruit of the LATINMETS (Latin America Metabolic Syndrome) project and the first collaborative effort by RIBESMET (Red Iberoamericana sobre el estudio del Síndrome Metabólico). The authors thank the following collaborators from the Licenciatura en Nutrición (Bachelor's Degree in Nutrition), who participated in the first stage of the study: Enriqueta Yolanda Castro Acosta, Iris Priscila Olivares Cano and Diana Gámez Romero. They also thank Celia de la Cruz Santana from the Departamento de Reproducción Humana, Crecimiento y Desarrollo Infantil, Centro Universitario de Ciencias de la Salud, Universidad de Guadalajara, and also thank their linguistic advisor, Robert Kimpleton.

\section{References}

1. Reaven GM (1988) Banting lecture 1988. Role of insulin resistance in human disease. Diabetes 37, 1595-1607. 
2. Dandona P, Aljada A, Chaudhuri A et al. (2005) Metabolic syndrome: a comprehensive perspective based on interactions between obesity, diabetes and inflammation. Circulation 111, 1448-1454.

3. Grundy SM, Cleeman JI, Daniels SR et al. (2005) Diagnosis and management of the metabolic syndrome: an American Heart Association/National Heart, Lung, and Blood Institute Scientific Statement. Circulation 112, 2735-2752.

4. Alberti KG, Zimmet P \& Shaw J (2006) Metabolic syndrome: a new world-wide definition. A Consensus Statement from the International Diabetes Federation. Diabet Med 23, 469-480.

5. Reaven GM (2006) The metabolic syndrome: is this diagnosis necessary? Am J Clin Nutr 83, 1237-1247.

6. Expert Panel on Detection, Evaluation, and Treatment of High Blood Cholesterol in Adults (2001) Executive summary of the third report of The National Cholesterol Education Program (NCEP) Expert Panel on Detection, Evaluation, and Treatment of High Blood Cholesterol in Adults (Adult Treatment Panel III). JAMA 285, 2486-2497.

7. Grundy SM, Brewer HB Jr, Cleeman JI et al. (2004) Definition of metabolic syndrome: report of the National Heart, Lung, and Blood Institute/American Heart Association conference on scientific issues related to definition. Circulation 109, 433-438.

8. Alberti KG, Eckel RH, Grundy SM et al. (2009) Harmonizing the metabolic syndrome: a joint interim statement of the International Diabetes Federation Task Force on Epidemiology and Prevention; National Heart, Lung, and Blood Institute; American Heart Association; World Heart Federation; International Atherosclerosis Society; and International Association for the Study of Obesity. Circulation 120, 1640-1645.

9. Grundy SM (2007) Metabolic syndrome: a multiplex cardiovascular risk factor. J Clin Endocrinol Metab 92, 399-404.

10. Isomaa B, Almaren P, Tuomi T et al. (2001) Cardiovascular morbidity and mortality associated with the metabolic syndrome. Diabetes Care 24, 683-689.

11. Huang PL (2009) A comprehensive definition for metabolic syndrome. Dis Model Mech 2, 231-237.

12. Lakka HM, Laaksonen DE, Lakka TA et al. (2002) The metabolic syndrome and total and cardiovascular disease mortality in middle-aged men. JAMA 288, 2709-2716.

13. Maggi S, Noale M, Gallina P et al. (2006) Metabolic syndrome, diabetes and cardiovascular disease in an elderly Caucasian cohort: the Italian Longitudinal Study on Aging. J Gerontol A Biol Sci Med Sci 61, 505-510.

14. Bataille V, Perret B, Dallongeville J et al. (2006) Metabolic syndrome and coronary heart disease risk in a populationbased study of middle-aged men from France and Northern Ireland. A nested case-control study from the PRIME cohort. Diabetes Metab 32, 475-479.

15. Pischon T, Hu FB, Rexrode KM et al. (2008) Inflammation, the metabolic syndrome and risk of coronary heart disease in women and men. Atherosclerosis 196, 392-399.

16. Taslim S \& Tai ES (2009) The relevance of the metabolic syndrome. Ann Acad Med Singapore 38, 29-33.

17. Wannamethee SG, Shaper AG, Lennon L et al. (2005) Metabolic syndrome vs. Framingham Risk Score for prediction of coronary heart disease, stroke and type 2 diabetes mellitus. Arch Intern Med 165, 2644-2650.

18. Balkau B, Charles MA, Drivsholm T et al. (2002) Frequency of the WHO metabolic syndrome in European cohort, and an alternative definition of an insulin resistance syndrome. Diabetes Metab 28, 364-376.

19. Buckland G, Salas-Salvadó J, Roure E et al. (2008) Sociodemographic risk factors associated with metabolic syndrome in a Mediterranean population. Public Health Nutr 11, 1372-1378.
20. Ford ES, Mokdad AH, Giles WH et al. (2003) Serum total cholesterol concentrations and awareness, treatment, and control of hypercholesterolemia among US adults: findings from the National Health and Nutrition Examination Survey, 1999 to 2000. Circulation 107, 2185-2189.

21. Azizi F, Salehi P, Etemadi A et al. (2003) Prevalence of metabolic syndrome in an urban population: Tehran Lipid and Glucose Study. Diabetes Res Clin Pract 61, 29-37.

22. Delavari A, Forouzanfar MH, Alikhani S et al. (2009) First nationwide study of the prevalence of the metabolic syndrome and optimal cutoff points of waist circumference in the Middle East: the national survey of risk factors for noncommunicable diseases of Iran. Diabetes Care 32, 1092-1097.

23. Ramanchandran A, Snehalatha C, Satyavani K et al. (2003) Metabolic syndrome in urban Asian Indian Adults: a population study using modified ATP criteria. Diabetes Res Clin Pract 61, 29-37.

24. Perez CM, Guzman M, Ortiz AP et al. (2008) Prevalence of the metabolic syndrome in San Juan, Puerto Rico. Ethn Dis 18, 434-441.

25. Mujica V, Leiva E, Icaza G et al. (2008) Evaluation of metabolic syndrome in adults of Talca city, Chile. Nutr J 7, 14.

26. Pinzon JB, Serrano NC, Diaz LA et al. (2007) Impact of the new definitions in the prevalence of the metabolic syndrome in an adult population at Bucaramanga, Colombia. Biomedica 27, 172-179.

27. Medina-Lezama J, Zea-Diaz H, Morey-Vargas OL et al. (2007) Prevalence of the metabolic syndrome in Peruvian Andean Hispanics: the PREVENCION study. Diabetes Res Clin Pract 78, 270-281.

28. Tull ES, Thurland A \& LaPorte RE (2005) Síndrome metabólico en personas nacidas en el Caribe con residencia en las Islas Vírgenes estadounidenses. Rev Panam Salud Publica 18, 418-426.

29. Gomez M, Ramirez M \& Disdier O (2006) Prevalence of the metabolic syndrome among a determined Puerto Rican population. P R Health Sci J 25, 111-116.

30. Florez H, Silva E, Fernandez V et al. (2005) Prevalence and risk factors associated with the metabolic syndrome and dyslipidemia in White, Black, Amerindian and Mixed Hispanics in Zulia State, Venezuela. Diabetes Res Clin Pract 69, 63-77.

31. Aguilar-Salinas CA, Rojas R, Gomez-Perez FJ et al. (2004) High prevalence of metabolic syndrome in Mexico. Arch Med Res 35, 76-81.

32. Marquezine GF, Oliveira CM, Pereira AC et al. (2008) Metabolic syndrome determinants in an urban population from Brazil: social class and gender-specific interaction. Int J Cardiol 129, 259-265.

33. Velasquez-Melendez G, Gazzinelli A, Correa-Oliveira R et al. (2007) Prevalence of metabolic syndrome in a rural area of Brazil. Sao Paulo Med J 125, 155-162.

34. Salaroli LB, Barbosa GC, Mill JG et al. (2007) Prevalence of metabolic syndrome in population-based study, Vitoria, ES-Brazil. Arq Bras Endocrinol Metabol 51, 1143-1152.

35. Escobedo J, Schargrodsky $\mathrm{H}$, Champagne $\mathrm{B}$ et al. (2009) Prevalence of the metabolic syndrome in Latin America and its association with sub-clinical carotid atherosclerosis: the CARMELA cross sectional study. Cardiovasc Diabetol 8, 52 .

36. Santos AC, Lopes C \& Barros H (2005) Prevalence of metabolic syndrome in the city of Porto. Rev Port Cardiol 23, 45-52.

37. Magi L, Stramenga C, Morosini P et al. (2005) Prevalence of the metabolic syndrome among Italian adults. Findings from the SIMAP study. Recenti Prog Med 6, 280-283.

38. Hanson R, Imperatore G, Bennett $P$ et al. (2002) Components of the 'metabolic syndrome' and incidence of type 2 diabetes. Diabetes 51, 3120-3127. 
39. Schutte AE, Shemesh T, Rowley K et al. (2005) The metabolic syndrome and changing relationship between blood pressure and insulin with age, as observed in Aboriginal and Torres Strait Islander peoples. Diabet Med 22, 1589-1597.

40. Rodríguez-Morán M, Guerrero-Romero F, Brito-Zurita O et al. (2008) Cardiovascular risk factors and acculturation in Yaquis and Tepehuanos Indians from Mexico. Arch Med Res 39, 352-357.

41. Meaney E, Lara-Esqueda A, Ceballos-Reyes GM et al. (2007) Cardiovascular risk factor in the urban Mexican population: the FRIMEX study. Public Health 121, 378-384.
42. Schulz LO, Bennet PH, Ravussin E et al. (2006) Effects of traditional and western environments on prevalence of type 2 diabetes in Pima Indians in Mexico and the US. Diabetes Care 29, 1866-1871.

43. Drewnowski A (2007) What's next for nutrition labeling and health claims: an update of nutrition profiling in the European Union and the United States. Nutr Today 42, 206-214.

44. Popkin B (2006) Global nutrition dynamics: the world is shifting rapidly toward a diet linked with noncommunicable diseases. Am J Clin Nutr 84, 289-298.

45. Colin M \& Loncar D (2006) Projections of global mortality and burden of disease from 2002 to 2030. PLos Med 3, 2011-2030. 